УДК 159.370923

DOI: https://doi.org/10.35619/iiu.v0i9.15

Бойко Наталія

старший викладач кафедри практики англійської мови Рівненського державного гуманітарного університету,

м. Рівне, України

ORCID: 0000-0002-2190-7512, e-mail: nataliya-boiko@ukr.net

\title{
РОЛЬ ВЧИТЕЛЯ, ВИХОВАТЕЛЯ, БАТЬКІВ ТА ІНДИВІДУАЛЬНИХ ОСОБЛИВОСТЕЙ ДІТЕЙ ДОШКІЛЬНОГО ВІКУ В НАВЧАННI ІНОЗЕМНОЇ МОВИ
}

\begin{abstract}
Анотація. У статті основна увага приділяється ролі вчителя і вихователя та тим загальним педагогічним і психологічним питанням індивідуального підходу, які вважаються важливими у навчанні дітей будь-якому передбаченому програмою предмету в дитячих навчальних закладах, зокрема й іноземній мові. Висвітлюються фактори, які сприяють раціональній організації навчального процесу з урахуванням особливостей пізнавальної діяльності дошкільника. Розглядаються також проблеми навчання іноземній мові в контексті всебічного розвитку дитини та підготовки іiї до школи.

У статті наголошується, що успіх в навчанні дітей іноземній мові в умовах закладу дошкільної освіти багато в чому залежить від урахування індивідуальних особливостей кожної дитини. Водночас знання індивідуальних особливостей кожної дитини допоможе вчителеві наперед визначити, які доручення давати дітям під час заняття, які ставити питання, як розподілити ролі під час розучування інсценувань та ін. Знаючи особливості групи в цілому і кожної дитини окремо, вчитель зможе правильно планувати колективні і індивідуальні завдання, не порушуючи загального ритму навчального процесу. Автор зазначає що, тільки за наявності психологічного контакту 3 групою в цілому i 3 кожною дитиною індивідуально, вчитель зможе зробити свої методичні розробки настільки мобільними, щоб процес навчання завжди підпорядковувався конкретній ситуації, що склалася.
\end{abstract}

Ключові слова: іноземна мова, дошкільне виховання, заклад дошкільної освіти, вихователь, вчитель, індивідуальний підхід.

Постановка проблеми. Ефективність раннього початку вивчення іноземної мови не викликає сумнівів у тому, що мова, вивчена в дитинстві, розкриває мовні й комунікативні здібності учнів. У процесі вивчення іноземної мови діти починають більш свідомо ставитися до рідної мови. Вони порівнюють рідну та іноземну мови, прислухаються до відмінностей в інтонаційному оформленні мови, що зрештою сприяє розумовому розвитку дитини. У процесі навчання іноземній мові в закладі дошкільної освіти усі діти отримують елементарні навички розмовної мови, оскільки навчання тут розглядається як підготовчий етап до занять у початковій школі. Наявність у дошкільнят елементарних навичок усної мови $€$ гарантією успішного оволодіння іноземною мовою на подальших етапах її вивчення.

Важлива роль у досягненні успіху в навчанні іноземній мові належить педагогу, його взаємодії з колективом, правильному вибору методів, прийомів, 
та засобів навчання. Однією $з$ основних умов взаєморозуміння між дітьми та вчителем, а отже й позитивного морального впливу на дітей в процесі навчання, $є$ любов педагога до дітей, знання закономірностей психічного розвитку дитини, iї здібностей, бажань, а також уміння проявляти чуйність i терплячість у випадках прояву недисциплінованості дітей. Педагог повинен не лише формувати у дитини уміння і навички усного мовлення, але й сприяти іiі розумовому, моральному та естетичному розвитку.

Аналіз останніх досліджень 3 проблеми. Опираючись на досвід психолінгвістики, сучасна дошкільна методика приділяє багато уваги дослідженню мови як складової частини діяльності людини, а також методам та прийомам навчання іноземній мові.

Проте, незважаючи на постійний інтерес до проблем раннього навчання іноземній мові і активізацію сучасних досліджень у цій освітній галузі (О. Б. Бігич, О. О. Коломінова, О. О. Леонтьєв, Р. Ю. Мартинова, О. Й. Негневицька, 3. М. Никитенко, В. М. Плахотник, Т. К. Полонська, С. В. Роман та ін.), питання проте, яким має бути зміст такого навчання, у яких формах, якими методами та за допомогою яких засобів воно має здійснюватися і хто саме має навчати дітей на сьогодні залишаються дискусійними.

Мета статті. Обгрунтування важливості ролі педагога та правильного вибору ним методів і прийомів навчання іноземній мові у закладі дошкільної освіти.

Виклад основного матеріалу дослідження. Іншомовна діяльність як новий спосіб спілкування дошкільника потребує створення позитивної мотивації, яка $є$ одним із найважливіших психологічних факторів успішності вивчення іноземної мови і ключовим питанням організації навчання.

Для правильної організації системи навчання іноземній мові дошкільників вчителю необхідно знати не лише їх вікові, а й індивідуальні особливості.

Педагогіка приділяє велику увагу питанню індивідуального підходу у навчанні в закладах дошкільної освіти. А. У. Запорожець і В. У. Давидов, які багато працювали в галузі дошкільного виховання, коментуючи правомірну, але в певних аспектах суперечливу концепцію Е. А. Аракіна, сформульовану ним в його відомій роботі «Ребенок в дошкольные годы», виражають повну солідарність з автором в питанні особистості дитини: «Дитина - це ще незріла істота, але вона особа, що стає особистістю, індивідуальністю, що має свої особливі потреби, нахили та інтереси, свої стосунки з дорослими і іншими дітьми, які глибоко переживаються, своє багате емоційне життя. I у всьому цьому дитина цілісна, єдина». (Запорожец, Давыдов, 1968, с. 9).

Кожна дитина приносить 3 собою в дитячий садок своє коло інтересів, свої радощі і засмучення, свої мрії і страхи. Ці індивідуальні якості проявляються певною мірою і під час першого заняття з іноземної мови: у більшості дітей спостерігається підвищена емоційність, схвильованість, обумовлена залученням до невідомої ще діяльності. Індивідуальні якості дітей педагог повинен враховувати вже з перших днів занять.

Ми вивчали досвід педагогічного колективу дошкільного навчального закладу № 44 з поглибленим гуманітарним розвитком м. Рівне, який розпочав експериментальну роботу з навчання дітей англійської мови 3 трирічного віку. Роботу розпочато у 1996 році. Навчання іноземній мові (англійській) ведеться 
за спеціально розробленою програмою (автор Н. Бойко), яка поступово доповнювалась та зміцнювалась.

На заняттях 3 іноземної мови деякі діти проявляють непосидючість, підвищену активність, бажання звернути на себе увагу. Це порушує загальний ритм занять і знижує їх ефективність. Так зазвичай поводяться діти з сильним, збудливим, але неврівноваженим типом нервової діяльності. Покарання або зауваження вчителя тут недоречні, оскільки вони ще більше збуджують дитину. Заспокоїти і організувати таких дітей можна тільки терпінням, спокійним, але вимогливим ставленням до них.

Поступово та завдяки надлишку нових вражень під час занять, у дітей 3'являється інтерес до них, розвивається увага, настає різкий перехід до кращої поведінки. На заняттях 3 англійської мови ми неодноразово були свідками подібних явищ.

«Таким чином, цілеспрямоване навчання сприяє поступовому посиленню гальмівного процесу в корі головного мозку, що попереджає подальші можливі «конфлікти» під час занять» (Тихеева, 1981, с. 25).

Як показує досвід, кожна дитина своєрідно, суто індивідуально сприймає новий матеріал, але так само своєрідно та індивідуально вона оцінює свої успіхи i реагує на них. Тому основною метою вчителя повинно стати прагнення до підпорядкування дитячої імпульсивності принципам розуму i логіки. При цьому він не застосовує ні примусу, ні покарання, а, користуючись методом переконання, допомагає дитині зорієнтуватися в правильності його вчинків. Безумовно, важко передбачати, який попереджувальний захід потрібен у кожному окремому випадку (це можна визначити в процесі роботи), але головне полягає в тому, щоб уважно стежити за поведінкою кожної дитини і враховувати їі індивідуальні особливості.

У процесі навчання дітей дошкільного віку іноземній мові ми спостерігали, що одні діти сприймають лексику, яка вивчається, за допомогою безперервної мовної комунікації (тобто постійно розмовляють), інші, навпаки, - за допомогою безсловесної комунікації (вони засвоюють мову мовчки). У такому випадку необхідно встановити таку рівновагу, яка давала б всім дітям можливість однаково опановувати як активне, так і пасивне мовлення. Але ця рівновага можлива лише тоді, коли вчитель знає не тільки те, про що говорить дитина, але і про що мовчить.

«За допомогою словесної комунікації, прислуховуючись до модуляції мови дитини, вчитель може виокремити ті емоційно-експресивні переживання, котрі $є$ домінуючим чинником у перспективному оцінюванні іi поведінки в процесі навчання» ( Негневицкая, Шахнарович, 1981, с. 46).

Тож на заняттях вчитель створює специфічне стимулююче середовище, яке дозволяє мовчазним дітям розвивати навички іноземної (як і рідної) усної мови.

«Зазвичай таке стимулююче середовище викликає певний шум в групі, який ми б назвали «корисним шумом» (Футерман, 1984, с. 25). Він виникає під час захоплюючої веселої гри, коли кожна дитина прагне назвати задане слово раніше інших і тому говорить голосніше ніж зазвичай. Цей шум визначається також тим, що деколи дитина щиро сміється, іноді ж в їі голосі з'являються нотки відчаю (якщо вона програє) і т. д. У подібних випадках вимагати тиші 3 педагогічної точки зору неправильно. Тиша взагалі не властива заняттям 
дошкільників. Тому необхідно постійно координувати шум і тишу під час проведення занять з іноземної мови.

Що ж до питання про «корисний шум» і «даремну тишу», то згідно 3 3. Футерманом (1984, с.25) слід сказати декілька слів про роль вихователя закладу дошкільної освіти в процесі навчання дітей іноземної мови.

Деякі вчителі іноземних мов 3 метою оптимального використання часу запрошують на заняття вихователя стежити за дисципліною в групі, мотивуючи це тим, що він добре знає індивідуальні особливості своїх вихованців. Але під час всього заняття вихователь прагне того, аби вся увага дітей була зосереджена на навчальному процесі. Не знаючи іноземної мови, не маючи уявлення про плани вчителя, він робить зауваження дітям, коли це зовсім не $\epsilon$ доречним, і переймаючись тишею, по суті, заважає роботі.

Висновки і перспективи подальших розвідок. Отже стає зрозумілим те, що присутність вихователя на заняттях з іноземної мови небажана, оскільки на заняттях він керується загальними вимогами до дисципліни, незважаючи на специфіку проведення занять з іноземної мови.

«Проблема онтогенезу особи дошкільника, як і сам процес іiі розвитку філогенезу, є об'єктом вивчення дошкільної психології і фізіології. Проте, перш ніж почати навчання дітей іноземній мові, вчитель повинен ознайомитися з основами цих наук, щоб спробувати проникнути у внутрішній світ дитини, як найретельніше вивчити його індивідуальні особливості» (Футерман, 1984, с. 27). В. Запорожець і В. Давидов ( 1968, с.6) пишуть що, «індивідуальний розвиток є глибоко своєрідним і саме носить конкретноісторичний характер, тобто залежить від конкретної громадської організації життя дитини».

«Вчитель-лінгвіст не може бути байдужим до прояву у деяких дітей вроджених або набутих унаслідок шкідливої звички мовних аномалій. Йому слід своєчасно проконсультуватися у лікаря щодо дітей з помітним розладом мови. Так, перш ніж навчати дитину, що заїкається, іноземній мові, необхідно звернутися до логопеда, щоб з'ясувати, які вправи будуть найбільш корисними для такої дитини» (Леонтьев, Рябова, 1970, с. 37). Зв’язок з логопедом, на нашу думку, $є$ вельми важливим ще й тому, що багато вправ, передбачених програмою навчання дошкільників іноземній мові, використовуються логопедами для лікування дітей.

Залучаючи дітей до активної мовної діяльності під час занять, вчитель спокійно, доброзичливо повинен пояснити їм, як важливо прислухатися до кожного звуку і слова в рідній та іноземній мові, що іноземну мову можна опанувати лише після того, як опануєш рідну мову: це навчить їх бути уважнішими до звукової сторони рідної та іноземної мов.

Зібравши всі анамнестичні відомості про дитину, вчитель з'ясовує, що більше всього приваблює іiі в процесі заняття, і дає їй можливість зайнятися мовними вправами, але не ізольовано, а разом з групою, що і дозволяє малюкові якнайповніше проявити свої мовні можливості. Як тільки дитина переконується, по-перше, у своїх успіхах, вона починає вірити в свої сили, і 3 ще більшим бажанням прагне вчитися.

Знання індивідуальних особливостей кожної дитини допоможе вчителеві наперед визначити, які доручення давати дітям під час заняття, які ставити питання, як розподілити ролі під час розучування інсценувань і ін. При цьому, 
звісно, він дотримується педагогічного такту і не дає приводу дитині думати, що у відношенні до неї робиться якийсь виняток.

Необхідність індивідуального підходу до дітей визначається ще і тим, що вчитель, котрий любить свою справу, ніколи не заспокоюється на досягнутому і весь час шукає більш довершені методи та прийоми навчання, продумує $\mathrm{i}$ враховує як загальні дидактичні принципи, так і особливості групи і кожної дитини.

Вчитель, який підтримує постійний контакт 3 батьками, швидше знаходить шляхи до здійснення індивідуального підходу. Тільки батьки знають індивідуальні особливості своєї дитини, іiі характер i звички, нахили i прагнення. Інформація батьків про поведінку дитини у поєднанні 3 характеристикою, яку складає вчитель, дає доволі повне уявлення про індивідуальні особливості дитини.

Підсумовуючи дослідження, ми приходимо до висновку, що успіх в навчанні дітей іноземній мові в умовах закладу дошкільної освіти багато в чому залежить від урахування індивідуальних особливостей кожної дитини.

Знаючи особливості групи в цілому і кожної дитини окремо, вчитель зможе правильно планувати колективні та індивідуальні завдання, не порушуючи загального ритму навчального процесу.

Тільки за наявності психологічного контакту 3 групою в цілому i 3 кожною дитиною окремо, вчитель зможе створити свої методичні розробки настільки мобільними, аби процес навчання завжди підпорядковувався конкретній ситуації, що склалася.

\section{СПИСОК ВИКОРИСТАНИХ ДЖЕРЕЛ:}

Запорожец, В., Давыдов, А. (1968). Труды Е.А. Аркина по проблемам развития и воспитания ребенка-дошкольника. Москва: Просвещение, с. 5-9.

Тихеева, Е. (1981). Развитие речи детей . Москва: Просвещение, 111 с.

Негневицкая, Е., Шахнарович, А. (1981) Язык и дети. Москва: Наука, с.18-26.

Футерман, 3. (1984). Иностранные языки в детском саду. Київ: Радянська школа. $144 \mathrm{c}$.

Леонтьев, А. та Рябова, Т. (1970). Актуальные проблемы психологии речи и психологии обучения языку. Москва: МГУ, с. 29-40.

Выготский, Л. (1996). Игра и ее роль в психическом развитии ребенка. Вопросы психологии, 6, с. 73-75.

Кулікова, І. та Шкваріна, Т. (2015). Англійська мова для дітей дошкільного віку : програма та методичні рекомендації. Тернопіль: Мандрівець, с.1-48.

Шкваріна, Т. (2007). Методика навчання іноземної мови дошкільників. Київ: Освіта України, 298 с.

Шкваріна, Т. (2005).Технологія засвоєння мовленнєвих зразків в ігровій діяльності. Дошкільне виховання : науково-методичний журнал МОН Украӥни, 9. Київ, Світоч. с. 18.

Шкваріна, Т. (2000) У світ іноземної мови з цікавістю. Дошкільне виховання: науково-методичний журнал Міністерства освіти $і$ науки Украӥни. №1. Київ: Світоч. s.22-231, c.22-23. 


\title{
REFERENCES:
}

Zaporozhets, V., Davydov, A. (1968). Trudy Ye.A. Arkina po problemam razvitiya $i$ vospitaniya rebenka-doshkolnika [E.A.Arkin's Works on the Problems of Development and Upbringing of a Preschool Child]. Moskva: Prosveshchenie, s. 5-9. [in Russian]

Tikheeva, Ye. (1981). Razvitie rechi detey [Development of Child's Speech]. Moskva: Prosveshchenie, 111 s. [in Russian]

Negnevitskaya, Ye. i Shakhnarovich, A. (1981) Yazyk $i$ deti [Language and Children]. Moskva: Nauka, s.18-26. [in Russian]

Futerman, Z. (1984). Inostrannye yazyki $v$ detskom sadu [Foreign Languages in Kindergarten]. Kyiv: Radianska shkola. 144 s. [in Russian]

Leontev, A. ta Ryabova, T. (1970). Aktualnye problemy psikhologii rechi $i$ psikhologii obucheniya yazyku [Actual Issues of Speech Psychology and Psychology of Language Teaching]. Moskva: MGU, s. 29-40. [in Russian]

Vygotskiy, L. (1996). Igra i ee rol v psikhicheskom razvitii rebenka [The Game and its Role in the Child's Mental Development]. Voprosy psikhologii, 6, c. 73-75. [in Russian]

Kulikova, I., Shkvarina, T. (2015). Anhliiska mova dlia ditei doshkilnoho viku: prohrama ta metodychni rekomendatsii [English for Preschool Children: Program and Methodical Recommendations]. Ternopil: Mandrivets. 48 s. [in Ukrainian]

Shkvarina, T. (2007). Metodyka navchanniia inozemnoi movy doshkilnykiv [Methodology of Teaching a Foreign Language for Preschool Children]. Kyiv: Osvita Ukrainy. 298 s. [in Ukrainian]

Shkvarina, T. (2005). Tekhnolohiia zasvoienniia movnykh zrazkiv v ihrovii diialnosti [Technology of Learning of Speech Patterns in Games] Doshkilne vykhovanniia: naukovo-metodychnyi zhurnal MON Ukrainy. 9. Kyiv: Svitych. s. 18. [in Ukrainian]

Shkvarina, T. (2000). U svit inozemnoi movy z tsikavistiu [In the World of a Foreign Language with interest]. Doshkilne vykhovanniia: naukovo-metodychnyi zhurnal MON Ukrainy. No 1. Kyiv: Svitych. s.22-23. [in Ukrainian]

\section{THE ROLE OF TEACHER, EDUCATOR, PARENTS AND INDIVIDUAL PECULIARITIES OF PRESCHOOL CHILDREN IN TEACHING THEM A FOREIGN LANGUAGE}

\author{
Natalia Boiko \\ Lecturer at the Department of Practice of the English Language, \\ Rivne State University of the Humanities, \\ Rivne, Ukraine \\ ORCID: 0000-0002-2190-7512 \\ e-mail: nataliya-boiko@ukr.net
}

\begin{abstract}
The article deals with the issues of foreign language teaching in children's educational establishments (kindergarten). It is distinguished. the role of a teacher and educator and some general pedagogical and psychological issues of an individual approach that are important in teaching foreign language, as well as any other subject, provided for by the curriculum in pre-school establishments,

The factors that promote the rational organization of educational process taking into account peculiarities of cognitive activity of preschool children are lighted, in particular psychological factors that require the educational process to be carried out in other forms, methods and techniques than in the training of younger and senior students. It is noted that the success of teaching foreign children in the conditions of a pre-school establishment depends largely on taking into account the individual characteristics of each
\end{abstract}


child, this will help the teacher to determine what tasks should be offered to preschool children during the classroom activity etc. Knowing the features of the group as a whole and each child in particular, the teacher will be able to correctly plan collective and individual tasks without breaking the overall rhythm of the educational process. The necessity of the individual approach to children is also determined by the fact that the teacher who loves his work never calms himself on the achievement and is always looking for more perfect methods and techniques of teaching, he thinks and takes into account both the general didactic principles and the features of the group and each child.

An important role in achieving success in teaching foreign language in a preschool establishment is given to the interaction of the teacher with the group, the right choice of methods, techniques, and means of teaching.

The author notes that only if there is psychological contact with the group as a whole and with each child individually, the teacher will be able to make his teaching materials so mobile that the learning process is always subject to a specific situation.

Key words: foreign language, primary education, kindergarten, individual approach.

Стаття надійшла до редакиії 14.02.2019 р. 